\title{
Lamina-Associated Polypeptide 2, Isoforms Beta/Gamma
}

National Cancer Institute

\section{Source}

National Cancer Institute. Lamina-Associated Polypeptide 2, Isoforms Beta/Gamma. NCI Thesaurus. Code C105103.

Lamina-associated polypeptide 2, isoforms beta/gamma (694 aa, $75 \mathrm{kDa}$ ) is encoded by the human TMPO gene. This protein is involved in the mediation of nuclear structure. 